\title{
PENGARUH MINAT BELAJAR DAN MOTIVASI BELAJAR SISWA KELAS VII SMPN 4 SIGI TERHADAP HASIL BELAJAR MATEMATIKA
}

\author{
Silfitrah $^{1}$, Wahyuni H. Mailili \\ ${ }^{1}$ Program Studi Pendidikan Matematika, FKIP, Universitas Alkhairaat \\ silfitrah7118@gmail.com \\ ${ }^{2}$ Program Studi Pendidikan Matematika, FKIP. Universitas Alkhairaat \\ nuning06match@gmail.com
}

\begin{abstract}
ABSTRAK
Tujuan dalam penelitian ini adalah untuk mengetahui pengaruh minat belajar dan motivasi belajar terhadap hasil belajar kognitif siswa materi himpunan di SMPN 4 Sigi. Jenis penelitian yang digunakan adalah expost facto dengan Populasi seluruh siswa kelas VII SMP Negeri 4 Sigi yang terdaftar pada tahun ajaran 2017/2018 sebanyak 248 siswa. Tehnik pengambilan sampelnya yaitu simple random sampling sehingga jumlah sampelnya 106 siswa, dengan metode pengumpulan datanya yaitu metode angket, dokumentasi, dan tes. Analisis datanya menggunakan uji korelasi product moment kemudian dilanjutkan uji regresi berganda. Hasil penelitian diperoleh regresi linear gandanya adalah $Y=7,478+0,086 X_{1}+0,091 X_{2}$. Melalui hasil penelitian serta pembahasan dalam analisis data disimpulkan bahwa: (1) Terdapat pengaruh yang signifikan antara minat belajar siswa kelas VII SMPN 4 Sigi terhadap hasil belajar matematika dengan nilai $T_{\text {hitung }} 2,298>T_{\text {tabel }} 1,98$ dan Taraf Sign $0.024<0,05$, (2) Terdapat pengaruh yang signifikan antara motivasi belajar siswa kelas VII SMPN 4 Sigi terhadap hasil belajar matematika, dengan nilai $T_{\text {hitung }} 2,256$ $>T_{\text {tabel }} 1,98$ dan Taraf Sign $0,026<0.05$, (3) Terdapat pengaruh yang signifikan antara minat belajar dan motivasi belajar siswa kelas VII SMPN 4 Sigi terhadap hasil belajar matematika, berdasarkan hasil uji F

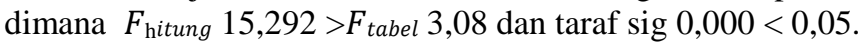

Kata Kunci : Minat, Motivasi, Hasil Belajar

\begin{abstract}
This study aims to determine the effect of learning interest and learning motivation on students' cognitive learning outcomes in set material in Sigi 4 Public Middle School.The type of research used is expost facto with a population of all seventh grade students of SMP Negeri 4 Sigi which were registered in the 2017/2018 school year with 248 students. Technic sampling that is simple random sampling so the sample size was106 students.The data collection methods are questionnaire, documentation, and test methods. Analysis of the data using the product moment correlation test then followed by multiple regression tests. The results obtained by double linear regression were $Y=7.478+0.086 X_{1}+0.091 X_{2}$. Based on the results of research and discussion of data analysis concluded that: (1) There is significant influence between interest in learning the learning outcomes of the mathematics class VII SMP Negeri 4 Sigi with ${ }_{r}$ $h$ itung value 2.298 $>_{r}$ tabel Sign level 1.98 and $0.024<0.05$, (2) There is significant influence between learning motivation towards learning outcomes math class VII SMP Negeri 4 Sigi, with ${ }_{r}$ h itung value 2.256> 1.98 and level ${ }_{T}$ tabel Sign $0.026<0: 05$, (3) There is significant relationship between learning and motivation to learn the learning outcomes of the mathematics class VII SMP Negeri 4 Sigi, based on test results $F$ where ${ }_{F}$ h itung 15.292 $>_{F}$ tabel sig level of 3.08 and $0.000<0,05$.
\end{abstract}




\section{PENDAHULUAN}

Pendidikan Merupakan suatu proses dengan cara tertentu, sehingga orang mendapatkan pengetahuan, pemahaman, dan cara bertingkah laku yang sesuai dengan kebutuhan. Dengan kata lain pendidikan juga adalah suatu kegiatan yang sifatnya kelembagaan dapat digunakan untuk melengkapi perkembangan individu dalam penguasaan pengetahuan, kebiasaan, sikap dan sebagainya (Muhibbin Syah, 2004).

Pendidikan bertujuan untuk menjadikan manusia yang baik dalam berbudi pekerti, yang luhur berdasarkan citacita dan nilai-nilai dalam bermasyarakat, mencerdaskan bangsa dalam rangka menyukseskan tujuan pendidikan formal. Dapat diartikan bahwa sukses atau gagalnya capaian dalam tujuan pendidikan itu bergantung pada mekanisme belajar yang dialami siswa, baik ketika ia di sekolah maupun di lingkungan tempat tinggal atau keluarganya sendiri.

Belajar merupakan sebuah proses yang tidak dapat dilihat secara nyata, prosesnya terjadi pada diri seseorang yang tengah mengalami belajar (Ngalim Purwanto, 2006). Belajar umumnya dipengaruhi oleh motivasi, baik secara internal maupun eksternal diri seseorang. Sebab motivasi adalah motor penggerak yang memacuh seseorang untuk mengerjakan sesuatu termasuk belajar olehnya tujuan belajar tercapai, maka dalam belajar matematika tentunya dibutuhkan motivasi yang besar agar siswa lebih berpeluang memperoleh nilai matematika yang tinggi.

Menurut Sudjana (1989) capaian hasil belajar siswa dipengaruhi oleh dua faktor utama yakni faktor internal diri siswa dan faktor eksternal diri siswa atau faktor lingkungan. Salah satu faktor internal (faktor dari dalam diri siswa) yang turut menentukan kesuksesan belajar siswa yakni minat. Minat adalah akar motivasi yang kuat untuk belajar dan menjadi pengantara partisipasi dan keaktifan siswa dalam proses pembelajaran. Hal yang sama diungkapkan oleh Slameto (2003) siswa yang mempunyai minat pada suatu subyek cenderung untuk memberikan ketertarikan yang lebih besar terhadap suatu subyek. Untuk meningkatkan minat belajar siswa, guru mempunyai peranan yang sangat penting. Guru hendaklah kreatif dalam menyusun metode penyampaian materi sebab cara pengajaran guru dapat mempengaruhi tinggi atau rendahnya minat belajar siswa.

$$
\text { Menurut Hudoyo }
$$

mengemukakan bahwa matematika adalah bidang ilmu yang terkait atau mengkaji konstruksi-konstruksi atau struktur-struktur yang abstarak dan keterkaitan diantara halhal itu. Untuk dapat memahami strukturstruktur serta keterkaitannya, tentu saja diperlukan pemahaman mengenai ide-ide yang terdapat didalam matematika itu.

Berdasarkan wawancara yang dilakukan pada hari kamis, 26 Oktober 2017 dengan ibu Anita, S.Pd selaku guru mata pelajaran matematika kelas VII di SMP Negeri 4 Sigi beliau mengungkapkan bahwa hasil belajar siswa pada materi pelajaran matematika dirasa masih kurang memuaskan, hal ini dibuktikan dengan hasil ulangan harian, ulangan tengah semester,ulangan akhir semester secara perorang yang nilainya selalu dibawah ratarata, walau secara klasikal sudah mencapai tingkat ketuntasan minimal yaitu 6,0. Disisi lain setiap pembelajaran matematika di kelas, siswa sering keluar masuk walau guru sedang memberikan materi. Kemampuan siswa dalam menyerap materi yang diberikan masih terlalu minim, kurangnya minat siswa menyebabkan motivasi belajarnya juga berkurang untuk mempelajari matematika, sehingga berpengaruh terhadap penguasaan materi pelajaran matematika yang berdampak akhir pada hasil belajar secara khusus untuk siswa itu sendiri, terlebih kepada pencapaian pembelajaran matematika secara umum.

Dalam mencapai kesuksesan belajar, perlu dipertimbangkan sekurang-kurangnya ada tujuh faktor yang tergolong kedalam faktor yang mempengaruhi hasil belajar. Faktor tersebut adalah: intelegensi, perhatian, minat, bakat, motivasi, kematangan, dan kelelahan (Slameto, 2003). Meskipun faktor dari metode belajar yang diaplikasikan oleh guru juga mempengaruhi peningkatan hasil belajar.

Hakekat minat adalah penerimaan akan sebuah koneksi antara individu dengan 
suatu diluar dari dirinya. Semakin besar atau dekat koneksi tersebut, semakin tinggi minatnya. Menurut Slameto (2003) minat merupakan suatu rasa yang besar terhadap rasa kesenangan dan ketertarikan pada sesuatu hal atau kegiatan, tidak dengan keterpaksaan dalam mengerjakannya. Hal lain dikemukankan oleh Muhibbin Syah (2003) minat merupakan kecondongan, kegairahan dan kecenderungan yang besar atau keinginan yang tinggi kepada sesuatu. Minat sangat berpengaruh pada kegiatan seseorang olehnya dengan minat ia akan mengerjakan sesuatu yang diminatinya. Sedangkan tanpa minat seseorang mustahil mengerjakan sesuatu. Dengan kata lain minat merupakan alasan seseorang melakukan sesuatu yang ia ingini. Minat belajar dapat kita diartikan sebagai kecenderungan dan ketertarikan yang konstan untuk mengamati dan terlibat dalam kegiatan belajar sebab sadar akan pentingnya atau berharganya hal yang ia pelajari.

Sardiman (2014), mendefenisikan bahwa motivasi erat kaitannya dengan kebutuhan. Oleh karena seseorang akan tertarik mengerjakan sesuatu bila merasa terdapat suatu kebutuhannya. Permasalahan motivasi ini, dapat juga dihubungkan dengan permasalahan minat. Minat didefenisikan sebagai suatu keadaan yang terjadi bila mana seseorang melihat karakteristik atau defenisi sementara kondisi yang dikaitkan dengan kemauan-kemauan atau kebutuhankebutuhannya sendiri. Oleh sebab itu, apa yang dipandang seseorang pasti akan meningkatkan minatnya sepanjang apa yang dipandangnya itu memiliki koneksi terhadap kepentingannya sendiri. Hal tersebut memperlihatkan bahwa minat adalah kecondongan dalam jiwa seseorang kepada seseorang (umumnya bersamaan dengan perasaan senang), sebab itu merasa bahwa terdapat kepentingan pada sesuatu itu. Menurut Bernard ( Sardiman, 2014) minat ada, bukan dengan tiba-tiba atau spontan, tetapi ada akibat dari keikutsertaan, pengalaman, kerutinan pada saat belajar dan bekerja. Maka jelas bahwa masalah minat akan selalu berhubungan dengan masalah kebutuhan atau keinginan, dan kebutuhan sangat erat hubungannya dengan motivasi.
Minat begitu berpengaruh dalam kegiatan belajar atau dengan kata lainnya minat sangat penting dalam proses belajar. Anakanak yang sangat malas dan kurang bergairah untuk belajar akan mengalami suatu ketidak berhasilan. Minat berkaitan dengan tingkat kebutuhan, semakin tinggi tingkat kebutuhan yang dirasakan seseorang maka semakin tinggi pula minat dan perhatiaanya untuk belajar akibatnya didapatkan prestasi belajar yang baik pula. Oleh sebab itu yang penting bagaimana membangun kondisi tertentu agar siswa selalu butuh dan mau terus belajar.

Terkait dengan penelitian yang dilakukan oleh Setyowati yang berkaitan dengan besarnya pengaruh motivasi belajar terhadap hasil belajar sebesar 29,766 sedangkan penelitian yang dilakukan oleh Fazri Sobari bersarnya pengaruh minat belajar terhadap hasil belajar sebesar 36,8\% sehingga disimpulkan minat dan motivasi cenderung mempengaruhi hasil belajar siswa olehnya peneliti tertarik untuk dilakukan penelitian.

Adapun tujuan penelitian ini adalah untuk menganalisis (1) Pengaruh minat belajar siswa kelas VII SMPN 4 Sigi terhadap hasil belajar matematika, (2) Pengaruh motivasi belajar siswa kelas VII SMPN 4 Sigi terhadap hasil belajar matematika, dan (3) Pengaruh minat belajar dan motivasi belajar siswa kelas VII SMPN 4 Sigi terhadap hasil belajar matematika.

\section{METODE PENELITIAN}

Penelitian ini dilaksanakan pada SMPN 4 Sigi, yang berlokasidi Jl. Trans Palu-Kulawi Km. 13 Dolo. Penelitian ini merupakan jenis penelitian ex-post facto. Penelitian ex-post facto dalam penelitian ini mengumpulkan fakta-fakta berupa data dan informasi untuk disusun dan dianalisis tentang pengaruh minatdanmotivasibelajar siswa terhadap hasil belajar matematika siswa.

Populasi dalam penelitian ini yaitu seluruh siswa kelas VII SMPN 4 Sigi yang berjumlah 248 orang. Tehnik pengambilan sampel pada penelitian ini adalah teknik sampling acak sederhana (Simple Random Sampling) sehingga didapatkan 106 orang siswa sebagai sampel dalam penelitian. 
Adapun tehnik dalam mengumpulkan data pada penelitian ini yaitu dengan menggunakan angket dan dokumentasi. Tehnik dalam menganalisis data digunakan pada penelitian ini yaitu analisis regresi berganda.

Adapun Jenis data yang diambil dalam penelitian ini yaitu data kualitatif berupa data tentang instrument minat belajar siswa $\left(\mathrm{X}_{1}\right)$ dan motivasi belajar siswa $\left(\mathrm{X}_{2}\right)$, sedangkan data kuantitatif berupa skor tes hasil belajar matematika siswa (Y).

Kaitan antara variable bebas dan variable terikat dapat diilustrasikan sebagai berikut:

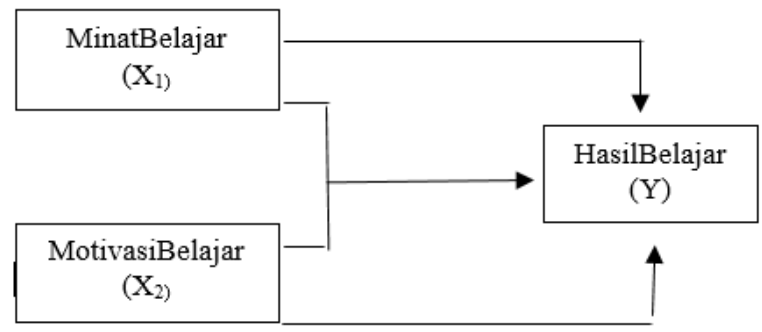

Gambar 1. Desain Penelitian

\section{HASIL DAN PEMBAHASAN}

Hasil penelitian yang didapatkan selama penelitian berlangsung dengan menggunakan SPSS yaitu hasil belajar kognitif siswa kelas VII SMP Negeri 4 Sigi dengan menyelesaikan soal pilihan ganda (PG) materi himpunan yang berjumlah 30 nomor sedangkan angket minat belajar dan motivasi belajar berjumlah 20 pernyataan.

\section{Deskripsi Minat Belajar $\left(\mathrm{X}_{1}\right)$}

Data hasil mengenai minat belajar siswa kelas VII SMP Negeri 4 Sigi diperoleh dari jawaban pada angket yang telah diberikan kepada 106 responden. Hasil dari jawaban responden dapat disajikan secara statistik pada Tabel 1

Tabel 1. Statistik Kuesioner Minat Belajar Siswa

\begin{tabular}{|c|c|}
\hline Statistik & Nilai Statis tik \\
\hline Mean & 64,56 \\
\hline Standar Deviasi & 9,87 \\
\hline Skor Tertinggi & 85 \\
\hline Skor Terendah & 37 \\
\hline Interval & 10 \\
\hline Rentang & 48 \\
\hline
\end{tabular}

\section{Motivasi Belajar $\left(\mathrm{X}_{2}\right)$}

Motivasi belajar siswa kelas VII SMPN 4 Sigi pada jawaban angket yang telah diberikan kepada 106 responden. Hasil dari jawaban responden dapat disajikan secara statistik pada Tabel 2

Tabel 2. Statistik Kuesioner MotivasiBelajar Siswa

\begin{tabular}{|c|c|}
\hline Statistik & Nilai Statistik \\
\hline Mean & 66,47 \\
\hline Standar Deviasi & 9,19 \\
\hline Skor Tertinggi & 85 \\
\hline Skor Terendah & 46 \\
\hline Interval & 8 \\
\hline Rentang & 39 \\
\hline
\end{tabular}




\section{Hasil Belajar (Y)}

Hasil belajar siswa kelas VII SMPN 4 Sigi melalui jawaban tes yang telah diberikan kepada 106 responden. Hasil dari jawaban responden dapat disajikan secara statistik pada Tabel 3.

Tabel 3. Statistik HasilBelajar Siswa

\begin{tabular}{|c|c|}
\hline Statistik & Nilai Statistik \\
\hline Mean & 19,05 \\
\hline Standar Deviasi & 3,02 \\
\hline Skor Tertinggi & 27 \\
\hline Skor Terendah & 12 \\
\hline Intervalnya & 3 \\
\hline Rentang & 15 \\
\hline
\end{tabular}

Berdasarkan perhitungan korelasi di atas, baik itu antara minat belajar terhadap hasil belajar, motivasi belajar terhadap hasil belajar dan minat belajar terhadap motivasi belajar semuanya berada dalam kategori sedang.

Berdasarkan analisis data tersebut, pada bagian ini jabarkan mengenai hasil pengujian hipotesis sebagai acuan membuat kesimpulan. Adapun hasil analisis uji hipotesis dijelaskan sebagai berikut:

\section{Pengaruh minat belajar terhadap hasil belajar matematika siswa kelas VII SMP Negeri 4 Sigi.}

Analisis data dengan menggunakan SPSS, memperlihatkan terdapat pengaruh yang signifikan minat belajar dengan hasil belajar matematika berdasarkan $t_{h}>t_{\text {tab }}$ sebesar 2,298 >1,98 dan nilai signifikansi. $0,024<0,05$. Ssebab nilai $0,024<0.05$, maka hipotesis kerja diterima yang berarti bahwa terdapat pengaruh yang berarti antara minat belajar siswa kelas VII SMPN 4 Sigi dengan hasil belajar matematika.

Persoalan minat belajar siswa biasanya ditunjukkan dari kegiatan belajar siswa sehari-hari dikelas, apakah siswa tersebut antusias dalam kelas, menyelesaikan jika dikasih soal atau PR oleh guru, menyimak jika guru menjelaskan. pastinya apabila siswa berminat pada sesuatu hal atau pelajaran dan ketika memperoleh kesulitan atau persoalan dalam pembelajaran akan menempuh usaha terusmenerus agar persoalannya dapat terselesaikan atau bertanya pada guru, didalam maupun diluar proses pelajaran tersebut akan selalu mengerjakan hal yang diminatinya atau proses belajar itu sendiri. Begitupun juga apabila siswa berminat pada pembelajaran, pada saat guru memaparkan penjelasan atau pelajaran tentunya akan dapat diterima dengan baik bagi siswa karena siswa akan lebih fokus pada suatu pembelajaran.

Selain berdasarkan hasil output SPSS, minat belajar dapat juga dilihat berdasarkan prosentase hasil angket minat belajar dengan kriteria yaitu:

Rendah Sekali $=\frac{42}{100}=(0,42)^{2} \times 100 \%=$ $17,64 \%$

Rendah $\quad=\frac{52}{100}=(0,52)^{2} \times 100 \%=$ $27,04 \%$

Sedang $=\frac{62}{100}=(0,62)^{2} \times 100 \%=$ $38,44 \%$

Tinggi $=\frac{72}{100}=(0,72)^{2} \times 100 \%=$ $51,84 \%$

Tinggi Sekali $=\frac{82}{100}=(0,82)^{2} \times 100 \%=$ $67,24 \%$

Berdasarkan persentase dari berbagai kriteria tersebut, terlihat bahwa yang persentasenya paling tinggi yaitu minat belajar siswa dengan kriteria tinggi sekali sebanyak $67,42 \%$. Hal ini berarti minat belajar siswa terhadap pelajaran matematika cukup baik. Minat belajar yang cukup baik karena hal dan keadaan yang berasal dari dalam diri siswa yang mendorongnya untuk 
belajar dan keadaan lingkungan di sekitarnya yang mendorong dirinya untuk melakukan kegiatan belajar. Misalnya cara mengajar guru, lingkungan sekolah, teman sepermainan,perhatian orang tua dan lain sebagainya.

Minat belajar siswa memiliki pengaruh terhadap pembelajaran Matematika. Dimana minat dapat menumbuhkan rasa ingin tahu peserta didik terhadap Matematika. Minat dapat ditumbuhkan dalam diri siswa. Guru memiliki peran dalam menumbuhkan minat belajar peserta didik dalam pembelajaran matematika. Salah satucara yang dapatdilakukan guru untuk meningkatkan minat peserta didik terhadap matematika adalah dengan menanamkan mind set baru tentang matematika.

Sering kali peserta didik memiliki mind set bahwa Matematika adalah sebuah momok menakutkan dalam hal pembelajaran. Sebagai guru, mengubah pola pikir peserta didik merupakan cara yang paling dasar, supaya peserta didik dapat menerima Marematika sebagai hal yang baru dan menyenangkan. Peran guru juga untuk meracik cara pengajaran dan pembelajaran Matematika semenarik mungkin. Sehingga, peserta didik perlahan dapat menumbuhkan minat belajar terhadap Matematika.

Ketika peserta didik mulai memiliki minat terhadap matematika maka, meskipun peserta didik mendapatkan kesulitan dalam pembelajaran mereka tidak akan lagi memiliki kecenderungan untuk menyerah dalam menyelesaikan soal tersebut. Karena ketika peserta didik memiliki minat maka, akan timbul rasa keingintahuan atau ketertarikan peserta didik untuk mencari jawaban dari soal tersebut.

Selain dalam proses pemecahan masalah, minat juga dapat meningkatkan daya tangkap pserta didik terhadap pelajaran matematika yang diberikan guru. Dimana pikirannya mulai terarah kepada pembelajaran dan dapat mengikuti alur pembelajaran tersebut. Hal ini mempunyai dampak besar bagi peserta didik. Hal ini karena, pembelajaran matematika yang disampaikan guru dapat diterima peserta didik dengan baik dan tujuan dari pembelajaran pun dapat dicapai, baik oleh guru maupun peserta didik.

Jadi dapatlah disimpulkan bahwa ada pengaruh minat belajar terhadap hasil belajar matematika siswa kelas VII SMPN 4 Sigi.

\section{Pengaruh motivasi belajar pada hasil belajar matematika siswa kelas VII SMP Negeri 4 Sigi.}

Analisis data dengan menggunakan SPSS, menunjukkan ada pengaruh yang signifikan antara motivasi belajar terhadap hasil belajar matematika berdasarkan $t_{h}>t_{\text {tab }}$ sebesar 2,256>1,98 dan nilai signifikansi. $0,026<0,05$. Sebab nilai $0,026<0.05$, sehingga hipotesis kerja diterima yang berarti terdapat pengaruh yang berarti antara motivasi belajar siswa kelas VII SMPN 4 Sigi terhadap hasil belajar matematika.

Selain berdasarkan hasil output SPSS, prosentase motivasi belajar berdasarkan hasil angket siswa dengan kriteria yaitu:

Rendah Sekali $=\frac{50}{100}=(0,5)^{2} \times 100 \%=$ $25 \%$

Rendah $\quad=\frac{58}{100}=(0,58)^{2} \times 100 \%=$ $33,64 \%$

Sedang $=\frac{66}{100}=(0,66)^{2} \times 100 \%=$ $43,56 \%$

Tinggi $=\frac{74}{100}=(0,74)^{2} \times 100 \%=$ $54,76 \%$

Tinggi Sekali $=\frac{82}{100}=(0,82)^{2} \times 100 \%=$ $67,24 \%$

Berdasarkan persentase dari berbagai kriteria tersebut, terlihat bahwa yang persentasenya paling tinggi yaitu minat belajar siswa dengan kriteria tinggi sekali sebanyak $67,42 \%$. Hal ini berarti motivasi belajar siswa terhadap pelajaran matematika cukup baik.

Kesuksesan dalam pembelajaran matematika tidak lepas dari guru bertindak sebagai fasilitator, informator, dan komunikator. Penerapan cara mengajar dipakai oleh guru dapat mempengaruhi interaksi antara guru, siswa, dan prestasi 
belajar. Hingga saat ini kita masih mendengar banyak siswa yang mengeluhkan bahwa matematika dilihat sebagai mata pelajaran yang menakutkan, tidak menarik, dan sulit untuk dikerjakan, juga tidak berhubungan langsung dengan kehidupan sehari-hari.

Memotivasi belajar sangat perlu hal ini dimaksudkan dalam proses pembelajaran sebab digunakan sebagai pendorong, penggerak, dan pengarahan pada kegiatan belajar. Motivasi merupakan prasyarat dalam pembelajaran, tanpa adanya motivasi hasil belajar yang dicapai tidak akan optimal dan motivasi sendiri adalah ketertarikan yang timbul dari dalam diri sendiri atau dimunculkan oleh keadaan sekitar. Motivasi yang terdapat pada seseorang akan menciptakan suatu perilaku yang mendorong pada tujuan untuk meraih sasaran. Keberhasilan belajar seseorang tidak jauh dari motivasi orang yang bersangkutan, oleh sebab itu pada hakekatnya motivasi belajar adalah faktor yang sangat menentukan kesuksesan belajar seseorang.

Tinggi rendahnya motivasi seseorang akan mempengaruhi kesuksesan belajar, olehnya motivasi perlu diupayakan terutama secara internal dalam diri maupun ketertarikan dari ekternal luar dengan cara memberi hadiah, penghargaan, pujian dan lain-lain. Dalam hal ini motivasi matematika penting sebab akan menetapkan strategi cara berfikir siswa yang benar untuk memahami suatu materi.

Motivasi dapat mengakibatkan terjadinya perubahan energi yang terdapat pada siswa, olehnya akan berpengaruh dengan persoalan gejala psikis, perasaan dan juga emosi, untuk selanjutnya bertindak atau mengerjakan sesuatu. Semua itu ketertarikan itu sebab terdapat tujuan, kebutuhan dan keinginan.

Berdasarkan pemaparan tersebut di atas maka motivasi belajar adalah keinginan atau ketertarikan, dorongan pada diri seseorang baik secara sadar maupun tidak sadar untuk mengerjakan sesuatu kegiatan dengan tujuan tertentu. Dalam hal ini penting siswa diberi perlakuan supaya timbul motivasi belajar pada diri siswa yaitu terbentuknya suatu kondisi tertentu sehingga siswa terdorong untuk belajar. Hal ini sesuai dengan indikator pada angket motivasi belajar siswa, yang mana untuk meningkatkan motivasi belajar siswa tidak terlepas dari pengaruh guru, lingkungan sekitar, teman dan lainnya.

Jadi dapatlah disimpulkan bahwa terdapat pengaruh motivasi belajar siswa kelas VII SMPN 4 terhadap hasil belajar matematika.

\section{Pengaruh minat dan motivasi belajar terhadap hasil belajar matematika siswa kelas VII SMP Negeri 4 Sigi.}

Analisis data dengan menggunakan SPSS yang memperlihatkan adanya pengaruh yang signifikan antara minat dan motivasi belajar dengan hasil belajar matematika berdasarkan Signifikansi Uji-F sebesar $0,000<0,05$ atau $F_{h}>F_{t}(15,292>$ 3,08 ) pada taraf Sign 0.05 (taraf 5\%), maka hipotesis kerja diterima yang artinya ada pengaruh antara minat dan motivasi belajar terhadap hasil belajar matematika siswa kelas VII SMP Negeri 4 Sigi.

Minat dan motivasi adalah salah satu sebab yang mempengaruhi hasil belajar, tidak hanya itu sebab-sebab lainnya seperti kematangan, intelegensi, perhatian, bakat, dan kelelahan. Apa yang telah peneliti artikan mengenai minat belajar yang baik dan motivasi belajar yang tinggi pastinya akan menghasilkan hasil belajar yang baik pula, dalam hal ini adalah matematika, itu adalah benar adanya.

\section{KESIMPULAN}

Berkaitan dengan tujuan penelitian yang telah dijelaskan di depan, maka dapat dibuat kesimpulan bahwa:

1. Terdapat pengaruh yang signifikan antara minat belajar siswa kelas VII SMPN 4 Sigi dengan hasil belajar matematika berdasarkah hasiluji $\mathrm{t}$ dengan nlait $_{\mathrm{h}}>\mathrm{t}_{\mathrm{t}}($ $2,298>1,98)$ dan berdasarkan taraf signifikannya yaituSign $0.024<0.05$.

2. Terdapat pengaruh yang signifikan antara motivasi belajar siswa kelas VII SMPN 4 Sigi dengan hasil belajar matematika berdasarkah hasil uji $t$ dengan nlait ${ }_{\mathrm{h}}>\mathrm{t}_{\mathrm{t}}($ $2,256>1,98)$ dan berdasarkan taraf signifikannya yaitu Sign $0.026<0.05$.

3. Terdapat pengaruh yang signifikan antara minat belajar dan motivasi belajar siswa 
kelas VII SMPN 4 Sigi pada hasil belajar matematika berdasarkah hasil uji $\mathrm{F}$ dengan nlai $\mathrm{F}_{\mathrm{h}}>\mathrm{Ft}(15,292>3,08)$ dan berdasarkan nilai signifikannya dengan nilai sign $0.000<0.05$.

\section{DAFTAR PUSTAKA}

Hudoyo. H. (2003). Pengembangan kurikulim dan pembelajaran matematika . malang : universitas negri malang

Purwanto, N. (2006). PsikologiPendidikan. Bandung:Rosdakarya

Sardiman, A.M. (2014). Interaksi dan MotivasiBelajar-Mengajar. Jakarta: Rajawali Pers.

Setyowati. (2007). Pengaruh Motivasi Belajar Terhadap Hasil Belajar Siswa Kelas VII SMP Negeri 13 Semarang Tahun Ajaran 2007. (online), (http://Journal.Unes.ac.id, Di aksess 23 November 2017)

Slameto. (2003). BelajardanFaktor-Faktor Yang Mempengaruhinya. Jakarta: Rineka Cipta.

Sobari, F. (2017). Pengaruh Minat Belajar Terhadap Hasil Belajar Siswa Pada Mata Pelajaran Ilmu Pengetahuan Sosial Di SMP Negeri 1 Jonggol Tahun Ajaran 2017. (online), (http://Journal.Uin.ac.id, Di akses 28 Februari 2018).

Sudjana, N. (1989). Dasar-dasar Proses Belajar Mengajar. Bandung: Sinar Baru Algensido.

Syah, M. (2004). Psikologi Belajar. Jakarta: PT Raja Grafindo Persada 